\title{
Possible pathogenic mechanism of gluteal pain in lumbar disc hernia
}

\author{
Yu Wang, Jin Yang, Yuqing Yan, Lifeng Zhang, Chuan Guo, Zhiyu Peng and Qingquan Kong*
}

\begin{abstract}
Recent reported results by Fang et al. published in BMC Musculoskeletal Disorders have added to the weight of evidence supporting association between gluteal pain and lumbar disc hernia. Their clinical finding shows the L4/5 level is the main level responsible for gluteal pain in lumbar disc hernia. Indeed, many possible mechanisms may explain why patients experience pain in the gluteal area. In this Correspondence, we would like to highlight several possible mechanisms of LDH-related gluteal pain based on detailed analysis of the sensory innervation of the gluteal region. We hope this can better explain the phenomenon found by Fang et al. We believe the principle mechanism is compression/irritation of L5 or S1 dorsal rami (intraspinal portion), which produce gluteal pain by irritating superior/medial cluneal nerve and referred pain from facet joints and sacroiliac joints. In addition, the presence of proximal sciatica could also induce gluteal pain. Lastly, fibers in the superior or inferior gluteal nerve could be compressed/irritated in LDH, inducing LDH-related gluteal pain. However, additional studies are needed in the future to delineate the exact mechanism(s).
\end{abstract}

Keywords: Gluteal pain, Lumbar disc hernia, Dorsal rami

We read the article "Which level is responsible for gluteal pain in lumbar disc hernia?" [1] published in BMC Musculoskeletal Disorders with great interest; first, we congratulate the authors for their informative work. In the study, the author collected single-level Lumbar Disc Hernia (LDH) patients who underwent Percutaneous Endoscopic Lumbar Discectomy (PELD). All patients were divided into two groups based on the presence of gluteal pain: gluteal pain (GP) and non-GP group. After analyzing the distribution of the levels and surgical outcome between the two groups, the authors confirmed the strong association between LDH and gluteal pain and concluded that L4/5 disc hernia was regarded as the primary factor of LDH-related gluteal pain. We are interested in this topic because we encountered 20 similar LDH-related gluteal pain patients in our department from January 2016 to June 2017.

In the study, a total of $94.6 \%$ of the $159 \mathrm{GP}$ patients were $\mathrm{L} 4 / 5 \mathrm{LDH}$, a much higher proportion than for L5/S1 (5.4\%) and L3/4 (0\%), thus indicating the apparent

\footnotetext{
* Correspondence: kqqspine@126.com

Department of Orthopedic Surgery, West China Hospital, Sichuan University, No. 37, Guoxue Lane, Wainan Street, Wuhou District, Chengdu 610041, No. 37, Guoxue
Sichuan, China
}

tendency for incidence of LDH-related gluteal pain in L4/ 5. The gluteal pain disappeared after surgery and reappeared with LDH recurrence, seemingly confirming the hypothesis. However, the author did not analyze the exact mechanism primarily based on the sensory innervation of the buttock region or the reasons for the high incidence in L4/5 LDH. Meanwhile, we cannot explain those patients whose gluteal pain syndrome was not relieved after PELD by this hypothesis. To be better understand, we'd like to talk about some possible pathogenic mechanism of LDH-related gluteal pain based on neuroanatomy of the buttock region.

As we know, sensory innervation of the buttock is complicated and controversial. We should be aware of the fact that the ventral roots include motor neurons, and the dorsal roots include sensory fibers that carry information from receptors in the peripheral nerves [2]. All spinal nerves combined with ventral and dorsal roots contain both motor and sensory fibers; they are designated mixed nerves $[3,4]$. Lateral branches of lumbar orsal rami compose the superior cluneal nerve (L1-3, sometimes L4, L5) and the medial cluneal nerve (S1-3), which innervate the upper-lateral and medial surface of the buttock [5-8]. The superior gluteal nerve (L4-S1) 
and the inferior gluteal nerve (L4-S2) coming from lumbar ventral rami dominate the movement of gluteus Minimus/Medius/Maximus also conduct their sensation [9-11]. Irritation of any above-mentioned nerves can produce gluteal pain. Other sources of gluteal pain include referred pain from lumbar facet joint $[5,12]$ or sacroiliac joint (SIJ) $[13,14]$, proximal sciatica after conservative management of radiculopathy [3], deep gluteal syndrome $[15,16]$ and dorsal rami injury during PELD, etc. In LDH-related gluteal pain, we believe the principal mechanism is the compression/irritation of the dorsal rami, especially the unseparated nerve fibers in the intraspinal portion, caused by LDH. On the one hand, in addition to L1-3, the lateral branch of L5 dorsal rami frequently join in the superior cluneal nerve. Meanwhile, lateral branches of the $\mathrm{S} 1$ dorsal rami form the medial cluneal nerve. Both cutaneous nerves innervate most of the buttock surface. On the other hand, facet joints innervated by each medial branch of dorsal rami and SIJ innervated by L4-S1 dorsal rami dorsally produce referred pain in buttock region when L5 and S1 dorsal rami, e.g., L4/5 or L5/S1 LDH, are compressed and irritated. In addition, as others reported, the presence of proximal sciatica could induce gluteal pain when L4-S1 nerve roots are injured [3]. Lastly, L5 and S1 ventral rami are also involved in the superior and inferior gluteal nerves that mediate sensation in the three major muscles of the buttock. Therefore, any possible mechanism mentioned above may produce gluteal pain in LDH, especially in L4/5 or L5/S1 level, which affect L5 and S1 nerve roots, respectively. More favorable studies about pathogenic mechanism of gluteal pain are needed in the future.

\section{Abbreviation}

GP: Gluteal pain; LDH: Lumbar disc hernia; PELD: Percutaneous Endoscopic Lumbar Discectomy; SIJ: Sacroiliac joint

\section{Authors' contributions}

$\mathrm{KOO}$ made substantial contributions to the conception, design of the study. WY was the main writer of the paper conceived the study idea and design. YJ, GC and YYQ contributed to literatures collection. PZY and ZLF contributed to language corrections. All authors read and approved the final manuscript.

Ethics approval and consent to participate

Not applicable.

Consent for publication

Not applicable.

\section{Competing interests}

The authors declare that they have no competing interests.

\section{Publisher's Note}

Springer Nature remains neutral with regard to jurisdictional claims in published maps and institutional affiliations.
Received: 13 May 2018 Accepted: 20 June 2018

Published online: 11 July 2018

\section{References}

1. Fang G, Zhou J, Liu Y, Sang H, Xu X, Ding Z. Which level is responsible for gluteal pain in lumbar disc hernia? BMC Musculoskelet Disord. 2016;17(1):356

2. Bogduk N. Functional anatomy of the spine. Handb Clin Neurol. 2016;136: 675-88.

3. Bartynski WS. Clinical, anatomic, and imaging correlation in spine-related pain: the essential elements. Tech Vasc Interv Radiol. 2009;12(1):2-10.

4. Bogduk N. The innervation of the lumbar spine. Spine. 1983;8:286-93.

5. Bogduk N, Wilson AS, Tynan W. The human lumbar dorsal rami. J Anat. 1982;134(Pt 2):383-97.

6. Saito T, Steinke H, Miyaki T, Nawa S, Umemoto K, Miyakawa K, et al. Analysis of the posterior ramus of the lumbar spinal nerve: the structure of the posterior ramus of the spinal nerve. Anesthesiology. 2013;118(1):88-94.

7. Maigne JY, Doursounian L. Entrapment neuropathy of the medial superior cluneal nerve. Nineteen cases surgically treated, with a minimum of 2 years' follow-up. Spine (Phila Pa 1976). 1997;22(10):1156-9.

8. Kuniya H, Aota Y, Kawai T, Kaneko K, Konno T, Saito T. Prospective study of superior cluneal nerve disorder as a potential cause of low back pain and leg symptoms. J Orthop Surg Res. 2014;9:139.

9. Hwang K, Nam YS, Han SH, Hwang SW. The intramuscular course of the inferior gluteal nerve in the gluteus maximus muscle and augmentation gluteoplasty. Ann Plast Surg. 2009;63(4):361-5.

10. Ling ZX, Kumar VP. The course of the inferior gluteal nerve in the posterior approach to the hip. J Bone Joint Surg Br. 2006;88(12):1580-3.

11. Akita K, Sakamoto H, Sato T. Origin, course and distribution of the superior gluteal nerve. Acta Anat (Basel). 1994;149(3):225-30.

12. Cohen SP, Raja SN. Pathogenesis, diagnosis, and treatment of lumbar zygapophysial (facet) joint pain. Anesthesiology. 2007;106(3):591-614.

13. Fortin JD, Dwyer AP, West S, Pier J. Sacroiliac joint: pain referral maps upon applying a new injection/arthrography technique. Part I: asymptomatic volunteers. Spine (Phila Pa 1976). 1994;19(13):1475-82.

14. Kurosawa D, Murakami E, Aizawa T. Referred pain location depends on the affected section of the sacroiliac joint. Eur Spine J. 2015;24(3):521-7.

15. Martin HD, Reddy M, Gomez-Hoyos J. Deep gluteal syndrome. J Hip Preserv Surg. 2015;2(2):99-107

16. Hernando MF, Cerezal L, Perez-Carro L, Abascal F, Canga A. Deep gluteal syndrome: anatomy, imaging, and management of sciatic nerve entrapments in the subgluteal space. Skelet Radiol. 2015:44(7):919-34.
Ready to submit your research? Choose BMC and benefit from:

- fast, convenient online submission

- thorough peer review by experienced researchers in your field

- rapid publication on acceptance

- support for research data, including large and complex data types

- gold Open Access which fosters wider collaboration and increased citations

- maximum visibility for your research: over $100 \mathrm{M}$ website views per year

At BMC, research is always in progress.

Learn more biomedcentral.com/submissions 